Article

\title{
Understanding the Effect of Multiple Domain Deletion in DNA Polymerase I from Geobacillus Sp. Strain SK72
}

\author{
Waqiyuddin Hilmi Hadrawi ${ }^{1}$, Anas Norazman ${ }^{1}$, Fairolniza Mohd Shariff ${ }^{1,2}$, \\ Mohd Shukuri Mohamad Ali ${ }^{1,3}$ and Raja Noor Zaliha Raja Abd Rahman 1,2,*(D)
}

1 Enzyme and Microbial Technology Research Centre, Faculty of Biotechnology and Biomolecular Sciences, Universiti Putra Malaysia, UPM Serdang 43400, Selangor Darul Ehsan, Malaysia; waqiyuddinhilmihadrawi@yahoo.com.my (W.H.H.); anasnorazman90@gmail.com (A.N.); fairolniza@upm.edu.my (F.M.S.); mshukuri@upm.edu.my (M.S.M.A.)

2 Department of Microbiology, Faculty of Biotechnology and Biomolecular Sciences, Universiti Putra Malaysia, UPM Serdang 43400, Selangor Darul Ehsan, Malaysia

3 Department of Biochemistry, Faculty of Biotechnology and Biomolecular Sciences, Universiti Putra Malaysia, UPM Serdang 43400, Selangor Darul Ehsan, Malaysia

* Correspondence: rnzaliha@upm.edu.my

Received: 8 July 2020; Accepted: 22 July 2020; Published: 15 August 2020

\begin{abstract}
The molecular structure of DNA polymerase I or family A polymerases is made up of three major domains that consist of a single polymerase domain with two extra exonuclease domains. When the N-terminal was deleted, the enzyme was still able to perform basic polymerase activity with additional traits that used isothermal amplification. However, the $3^{\prime}-5^{\prime}$ exonuclease domain that carries a proofreading activity was disabled. Yet, the structure remained attached to the $5^{\prime}-3^{\prime}$ polymerization domain without affecting its ability. The purpose of this non-functional domain still remains scarce. It either gives negative effects or provides structural support to the DNA polymerase. Here, we compared the effect of deleting each domain against the polymerase activity. The recombinant wild type and its variants were successfully purified and characterized. Interestingly, SK72-Exo (a large fragment excluding the $5^{\prime}-3^{\prime}$ exonuclease domain) exhibited better catalytic activity than the native SK72 (with all three domains) at similar optimum temperature and $\mathrm{pH}$ profile, and it showed longer stability at $70^{\circ} \mathrm{C}$. Meanwhile, SK72-Exo2 (polymerization domain without both the $5^{\prime}-3^{\prime}$ and $3^{\prime}-5^{\prime}$ exonuclease domain) displayed the lowest activity with an optimum at $40{ }^{\circ} \mathrm{C}$ and favored a more neutral environment. It was also the least stable among the variants, with almost no activity at $50{ }^{\circ} \mathrm{C}$ for the first $10 \mathrm{~min}$. In conclusion, cutting both exonuclease domains in DNA polymerase I has a detrimental effect on the polymerization activity and structural stability.
\end{abstract}

Keywords: SK72 DNA polymerase I; polymerase domain; 5'-3' exonuclease domain; 3'-5' exonuclease domain; proofreading activity

\section{Introduction}

Deoxyribonucleic acid (DNA) polymerase plays a key role in maintaining the genetics information of an organism from one generation to another through the catalysis of double-stranded DNA [1]. This enzyme plays a significant role in the DNA repair pathway to secure the integrity of genetic materials by proofreading and recorrecting any mismatched nucleotide [2,3]. In general, DNA polymerase enzymes have been categorized into seven different families termed as A, B, C, D, $\mathrm{X}, \mathrm{Y}$, and RT according to their similarity in amino acid sequences as well as elucidated structure analyses $[4,5]$. It is noteworthy that family A polymerases are widely studied due to their interesting 
structure, which mimics the right hand in humans, and their recent applications in isothermal amplification [6,7].

Family A polymerases, referred to as DNA polymerase I, have three major domains that work as a single chain protein, namely: (1) the $5^{\prime}-3^{\prime}$ polymerase domain, (2) the $5^{\prime}-3^{\prime}$ exonuclease domain, and (3) the $3^{\prime}-5^{\prime}$ exonuclease domain (absent in some enzymes) [8]. The crystal structure of family A polymerases reveal their structural organization and the division of their conserved $5^{\prime}-3^{\prime}$ polymerase domain into three subdomains called the palm, finger, and thumb. The palm domain plays a role in catalyzing the transfer of phosphoryl groups in the phosphoryl transfer reaction that catalyzes by a two-metal-ion mechanism. The finger domain appears to function in the binding of nucleoside triphosphates with the template base. The thumb domain plays a potential role in the processivity, translocation, and positioning of the DNA. Meanwhile, the $5^{\prime}-3^{\prime}$ exonuclease domain serves as filling for the gaps present in the Okazaki fragment at the lagging strand, and the $3^{\prime}-5^{\prime}$ exonuclease domain plays a role in DNA excision repair processes [9-11].

In 1997, the large fragment of DNA polymerase I from Geobacillus stearothermophilus (previously Bacillus stearothermophilus) namely Bst-DNA polymerase was successfully characterized and crystallized $[12,13]$. Bst-DNA polymerase is widely used in loop-mediated isothermal amplification (LAMP) due to its thermolabile characteristic (optimum at $60^{\circ} \mathrm{C}$ ) and inherent strand displacement activity [14]. The Bst-DNA polymerase fragment showed high similarity with the Klenow fragment from $E$. coli that comprised only two major domains $\left(3^{\prime}-5^{\prime}\right.$ exonuclease and $5^{\prime}-3^{\prime}$ polymerase domains). This shows that the Bst-DNA polymerase is still able to retain its enzymatic activity even by cutting one of the major domains, the $5^{\prime}-3^{\prime}$ exonuclease domain. The $3^{\prime}-5^{\prime}$ exonuclease domain in Bst-DNA polymerase that carries a proofreading activity is expected to be non-functional due to the lack of conserved residue, which is responsible for the catalytic reaction [15-17]. It is further confirmed by understanding the absence of divalent metal ion interaction among the exonuclease site with the DNA template [13]. Yet, the structure remains attached with the $5^{\prime}-3^{\prime}$ polymerase domain without affecting its polymerization activity.

The effect of truncation on enzymes, either a few amino acid residues or the major domain, is often investigated and compared to its wild type, which results in improved biological function and structural properties. For instance, a study by Kamaruddin et al. observed an improved crystallizability and anti-aggregation property of AT2 lipase from Staphylococcus epidermis AT2 with the removal of only four residues on the C-terminal region [18]. Meanwhile, Lamers et al. reported a DNA polymerase III with an additional domain called Polymerase and Histidinol Phosphatase (PHP). However, the function of this domain is still not entirely understood, as it presumably serves as a proofreading subunit or is likely to be catalytically inactive in some organisms. Thus, deletion of the $60 \mathrm{~N}$-terminal residue showed a loss of activity and suggested that the PHP domain was responsible for maintaining the structural integrity $[19,20]$. Aother study on the domain structure in polymerase also concluded that the existence of a tethered domain in rat DNA polymerase $\beta$ influenced the stability and folding of the structure as well as the functional and regulatory properties [21].

In this present work, our aim was to understand the effect of the truncation of multiple domains in SK72 DNA polymerase I. Until now, a comparative study between the full-length DNA polymerase I from Geobacillus sp. and its Klenow-like fragments has been poorly understood. Moreover, the sole purpose of a non-functional $3^{\prime}-5^{\prime}$ exonuclease domain still remains unknown; either it only provides structural support or it damages the function of the polymerase activity. Hence, concerted efforts into understanding the effect of multiple domain deletion in DNA polymerase I is necessary and merits scientific attention. Here, DNA polymerase I (SK72 DNA polymerase I) from Geobacillus sp. SK72 isolated from Sungai Kelah hot spring in Perak, Malaysia was used. Several polymerase recombinants were designed where each had a varied number of domains in existence. The polymerase recombinants were further characterized based on their effect toward the biochemical and biophysical properties. The data obtained could provide insights into the effect of major domain deletion in SK72 DNA polymerase I as well as the whole family A polymerase. 


\section{Results and Discussion}

\subsection{Conserved Domain and Structure Analyses}

The SK72 DNA polymerase I gene was encoded for 878 polypeptides with an approximate molecular weight and isoelectric point (pI) of $100 \mathrm{kDa}$ and 5.53, respectively. The $\mathrm{N}$-terminal containing the $5^{\prime}-3^{\prime}$ exonuclease domain was located at residues 1 to 298 . The central region of the SK72 DNA polymerase I was made up of a 3'-5' exonuclease domain (residue 299 to 469), and the C-terminal bearing $5^{\prime}-3^{\prime}$ polymerase domain started at residue 470 to 878 (Figure 1). Overall, the amino acids consisted of $15.8 \%$ negatively charged (Asp + Glu) and 13.4\% positively charged (Arg + Lys) residues at neutral $\mathrm{pH}$. The percentage of total charged residues (Arg, Lys, His, Asp, and Glu) in the enzyme was 30.3\%. Moreover, the hydrophobic amino acid residues (Ala, Phe, Ile, Leu, Met, Pro, Val, and Trp) occupied $44.6 \%$ of total SK72 DNA polymerase I amino acids.

Overall, SK72 DNA polymerase I shares a similar structural framework with DNA polymerase I, consisting three major domains (2 exonucleases and 1 polymerase domains). These domains were identified against three online databases, namely Conserved Domain Search (CDS), InterPro Scan, and Protein Families (Pfam). The domains were further analyzed by predicting their secondary structure by Position-Specific Iterative Basic Local Alignment Search Tool (PSI-BLAST) based secondary structure prediction (PSIPRED) and coupled with comparative modeling software called YASARA to verify the domain boundaries and suitable initial residue for each variant. Absence of the full-length structure of DNA polymerase I from Geobacillus sp.; Taq polymerase (1TAQ), served as the most reliable template for SK72 DNA polymerase I in the secondary structure prediction and homology modeling, despite having low identity (42\%). Meanwhile, Klenow-like polymerase from G. stearothermophilus (3TAN) was used for other variants (SK72-Exo and SK72-Exo2) with 99\% sequence identity. This is to identify the suitable starting residue and prevent any unwanted cutting of non-important structure that might interfere with the folding and stability of the structure. Most of the $\alpha$-helix and $\beta$-strand structures were preserved, as they were indicators of protein stability [22]. Thus, the codon at the coil structure was used as the initial codon for each variant.

\begin{tabular}{l}
\hline MRLKKKLVLIDGSSVAYRAFFALPLLHNDKGIHTNAVYGFTMMLNKILAEEEPTHMLV \\
AFDAGKTTFRHEAFQEYKGGRQQTPPELSEQFPLLRELLRAYRIPAYELENYEADDIIG \\
TLAARAEQEGFEVKVISGDRDLTQLASPHVTVDITKKGITDIEPYTPETVREKYGLTPEQ \\
IVDLKGLMGDKSDNIPGVPGIGEKTAVKLLRQFGTVENVLASIDEIKGEKLKETLRQHR \\
EMALLSKKLAAIRRDAPVELSLDDIVYQGEDREKVVALFKELGFQSFLEKMESPSSEEE \\
KPLAKMAFTLADRVTEEMLADKAALVVEVVEENYHDAPIVGIAVVNEHGRFFLRPETA \\
LADPQFVAWLGDETKKKSMFDSKRAAVALKWKGIELCGVSFDLLLAAYLLDPAQGVD \\
DVAAAAKMKQYEAVRPDEAVYGKGAKRAVPDEPVLAEHLVRKAAAIWELERPFLDEL \\
RRNEQDRLLVELEQPLSSILAEMEFAGVKVDTKRLEQMGKELAEQLGTVEQRIYELAG \\
QEFNINSPKQLGVILFEKLQLPVLKKTKTGYSTSADVLEKLAPYHEIVENILHYRQLGKL \\
QSTYIEGLLKVVRPDTKKVHTIFNQALTQTGRLSSTEPNLQNIPIRLEEGRKIRQAFVPS \\
ESDWLIFAADYSQIELRVLAHIAEDDNLMEAFRRDLDIHTKTAMDIFQVSEDEVTPNM \\
RRQAKAVNFGIVYGISDYGLAQNLNISRKEAAEFIERYFESFPGVKRYMENIVQEAKQK \\
GYVTTLLHRRRYLPDITSRNFNVRSFAERMAMNTPIQGSAADIIKKAMIDLNARLKEER \\
LQARLLLQVHDELILEAPKEEMERLCRLVPEVMEQAVTLRVPLKVDYHYGSTWYDAK \\
\hline
\end{tabular}

Figure 1. Amino acid sequence of the SK72 DNA polymerase I. Note: 5'-3' exonuclease domain (blue region), $3^{\prime}-5^{\prime}$ exonuclease domain (red region), and $5^{\prime}-3^{\prime}$ polymerase domain (yellow region).

Figure 2 shows that all the predicted models were able to maintain the structural integrity of DNA polymerase I, especially the polymerase catalytic region. Although the $3^{\prime}-5^{\prime}$ exonuclease domain was located near the polymerization domain, the deletion of both exonuclease domains did not disrupt the overall shape of the polymerization domain entirely. The full-length structure was dominated 
by the $\alpha$-helical structure with $51.2 \%$, followed by $10.7 \%$ and $38.1 \%$ of $\beta$-strand and other structures, respectively, while the number of helix and strand structures in SK72-Exo and SK72-Exo2 were reduced prior to the elimination of the domain. All structures displayed an open-state formation where the thumb and finger subdomain were distant from each other and exposed the catalytic site located at the palm subdomain, while allowing the access of the DNA template [23,24]. $\mathrm{A} \mathrm{Mg}^{2+}$ ion was predicted to react with the polymerase active site at the position of Tyr 654, Asp 653, and Asp 830, which acted as a cofactor and initiated the nucleotide addition $[25,26]$. The overall quality of all the models falls between $95 \%$ and $98 \%$, which is within that of a reliable and good folded protein.

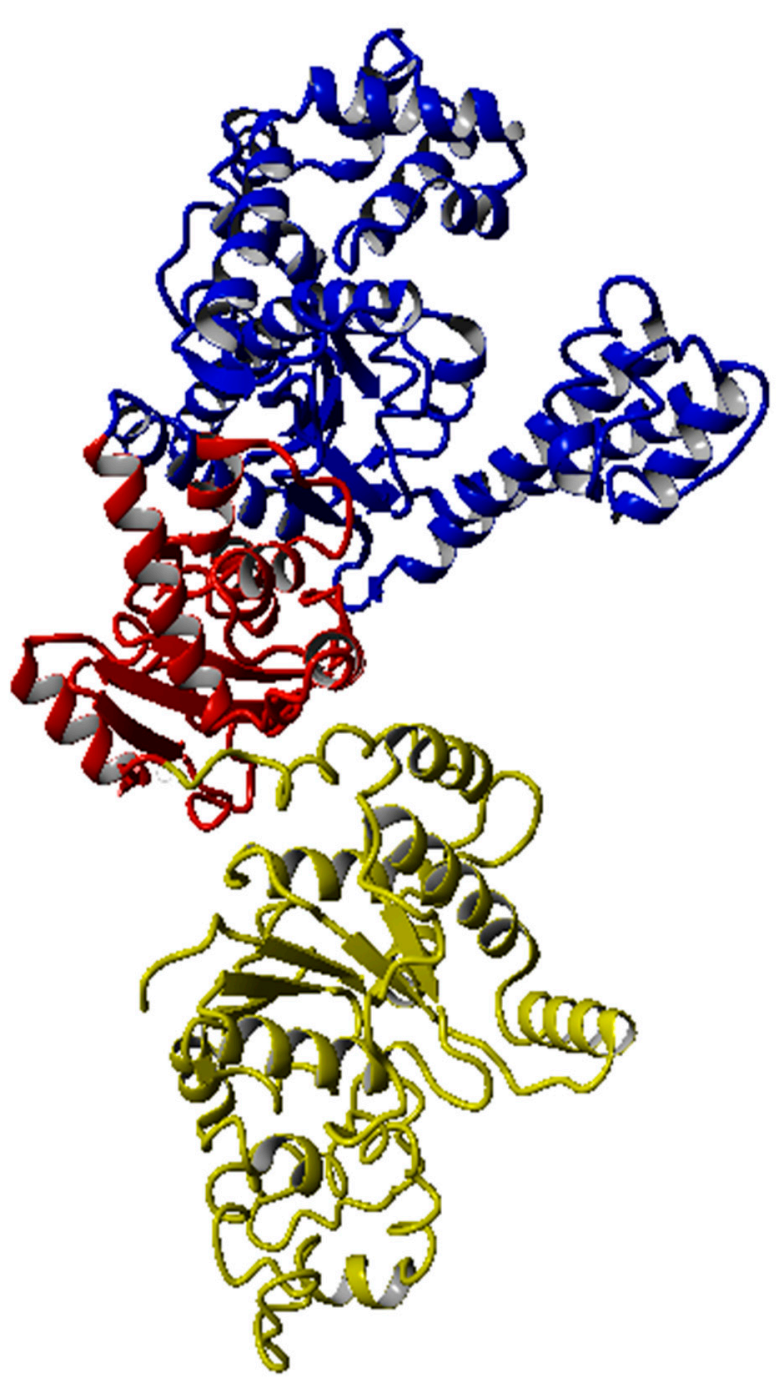

(a)

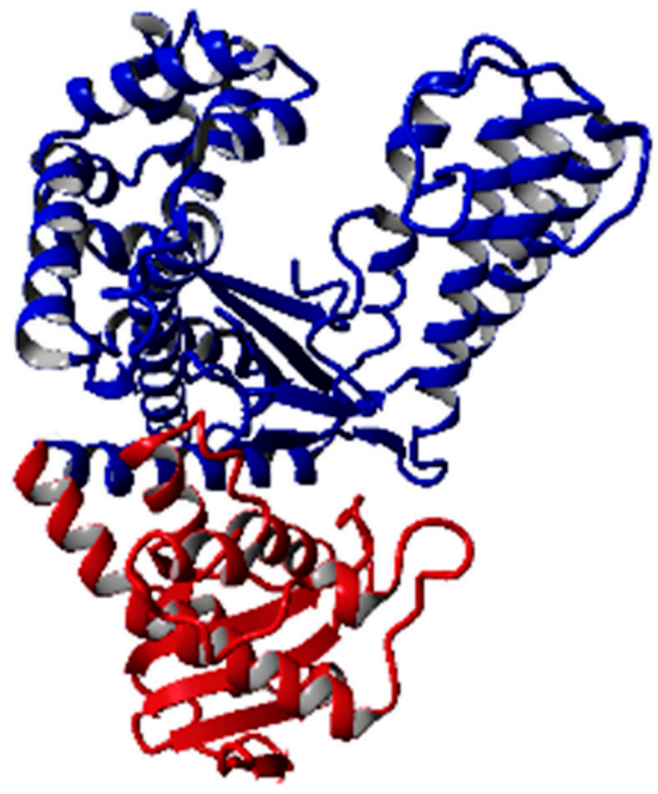

(b)



(c)

Figure 2. Modeled structures of SK72 DNA polymerase. (a) SK72 DNA polymerase, (b) SK72-Exo, and (c) SK72-Exo2. Note: $5^{\prime}-3^{\prime}$ polymerase domain (blue), $3^{\prime}-5^{\prime}$ exonuclease domain (red), and $5^{\prime}-3^{\prime}$ exonuclease domain (yellow).

\subsection{Cloning, Overexpression, and Purification of SK72 DNA Polymerase I and Its Variants}

Three recombinant constructs were designed, namely: (1) SK72, SK72 DNA polymerase I containing all three major domains; (2) SK72-Exo, SK72 DNA polymerase I with a deleted N-terminus 5'-3' exonuclease domain, and (3) SK72-Exo2, SK72 DNA polymerase I with only the polymerase domain. All constructs were fused with a polyhistidine tag on the N-terminus region (Figure 3 ). 
The overexpression for each construct varied. For SK72 and SK72-Exo, the production of proteins was accumulated in the form of soluble parts at $37^{\circ} \mathrm{C}$ for $12 \mathrm{~h}$ with $0.25 \mathrm{mM}$ of Isopropyl $\beta$ d-1-thiogalactopyranoside (IPTG) induction. Meanwhile, the SK72-Exo2 was overexpressed at $16^{\circ} \mathrm{C}$ for $12 \mathrm{~h}$ with $0.5 \mathrm{mM}$ of IPTG induction, as the protein showed insoluble expression at $37^{\circ} \mathrm{C}$ and $25{ }^{\circ} \mathrm{C}$ of incubation. This suggests that the expression at low temperature helps to reduce protein aggregations and assist in protein folding, thus decreasing the formation of inclusion bodies [27,28]. Then, the crude enzymes obtained underwent heat treatment at $60{ }^{\circ} \mathrm{C}$ for $30 \mathrm{~min}$ to reduce some background expression except for SK72-Exo2 due to its protein instability. All proteins were successfully purified via single-step purification using $\mathrm{Ni}^{2+}$ Sepharose affinity chromatography with almost $80 \%$ of impurities eliminated (Figure 3). The purified proteins were further subjected to the desalting procedure prior to characterization.

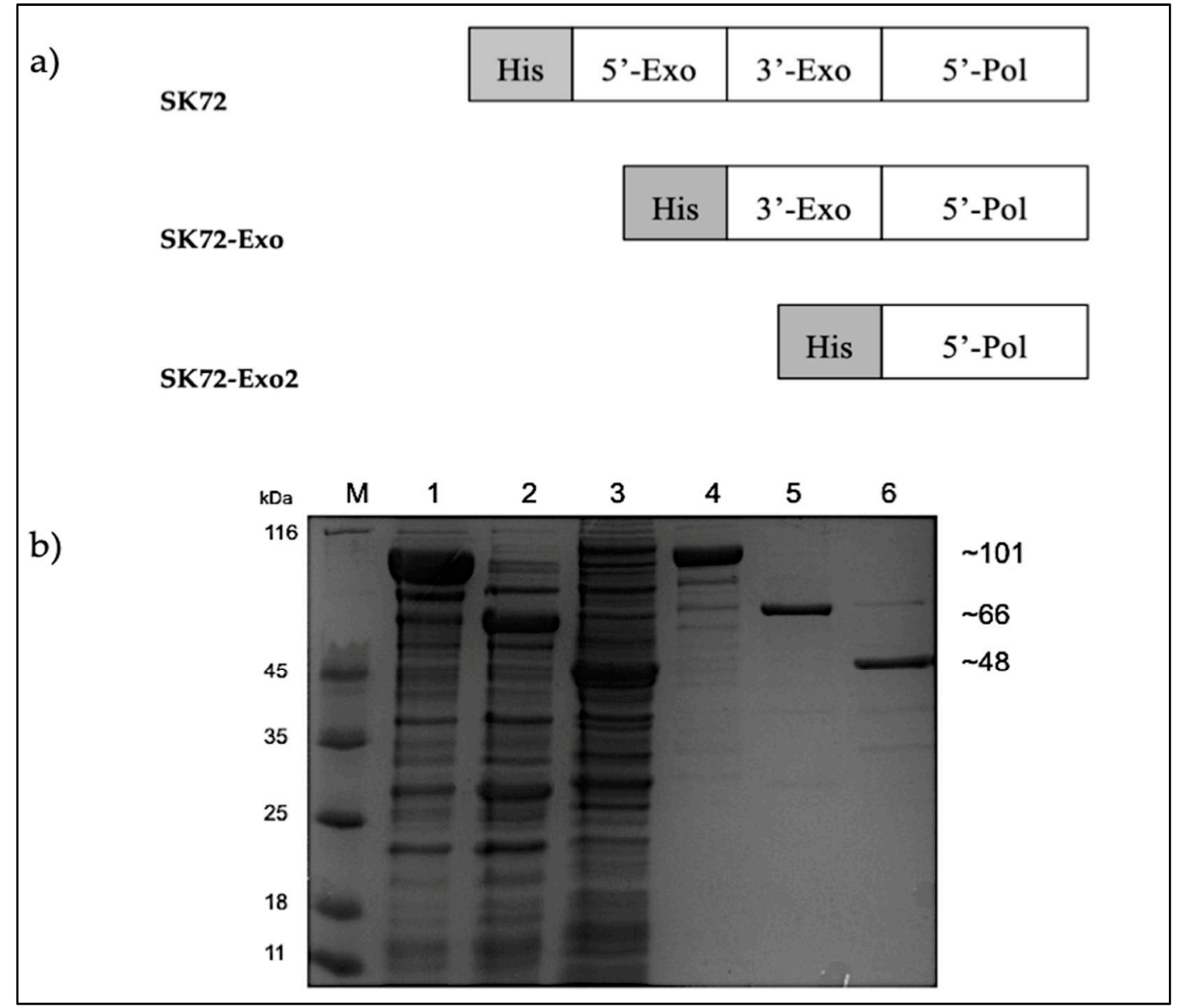

Figure 3. The SK72 DNA polymerase I and its variants. (a) Schematic representation of SK72 DNA polymerase I and its variants fused with a polyhistidine tag. (b) Expression and purification of SK72 DNA polymerase I and its variants. The overexpressed (lane 1 to 3 ) and purified (lane 4 to 6 ) of SK72 DNA polymerase I and its variants. Note: SK72 (lanes 1 and 4), SK72-Exo (lanes 2 and 5), SK72-Exo2 (lanes 3 and 6), and $M=$ unstained protein marker (Thermo Fisher, City, Waltham, MA, USA).

\subsection{Characterization of SK72 DNA Polymerase I and Its Variants}

\subsubsection{Effect of Temperature on SK72 Polymerase Activity and Its Variants}

Characteristics of the SK72 DNA polymerase I and its variants were determined using a standard DNA polymerase assay with a final concentration of $2 \mu \mathrm{g} / \mu \mathrm{L}$ [29]. The effect of temperature on SK72 DNA polymerase activity was studied by measuring the activity from 20 to $80^{\circ} \mathrm{C}$ with an interval of $10{ }^{\circ} \mathrm{C}$. In comparison with all three variants, SK72-Exo demonstrated the highest polymerase 
activity profile, followed by SK72 and finally SK72-Exo2 with $72.1 \mathrm{U} / \mathrm{mL}, 48.3 \mathrm{U} / \mathrm{mL}$, and $21.8 \mathrm{U} / \mathrm{mL}$, respectively (Figure 4). Interestingly, both SK72 and SK72-Exo showed similar optimum temperature activity at $60^{\circ} \mathrm{C}$ but dropped at $70^{\circ} \mathrm{C}$. This shows that the deletion of the $5^{\prime}-3^{\prime}$ exonuclease domain had no effect on the temperature profile but enhanced the polymerase activity, suggesting that the $\mathrm{N}$-terminal domain deletion promoted better flexibility and rigidity [30]. Similar phenomena were also monitored with the alkaline $\alpha$-amylase Amy703, where the effect of deletion of its N-terminal domain (N-Amy) caused an increase of optimum temperature from 40 to $50^{\circ} \mathrm{C}$ [31,32]. Meanwhile, the SK72-Exo2 achieved its optimum activity at $40{ }^{\circ} \mathrm{C}$, which is slightly lower compared to SK72 and SK72-Exo. Obviously, deleting both exonucleases brought a major effect on the core catalytic site; it lowered the optimum activity and shifted the temperature profile $20{ }^{\circ} \mathrm{C}$ to the left. At $50{ }^{\circ} \mathrm{C}$, the activity rapidly inactivated with a total inhibition at higher temperature that might disrupt the structural integrity of SK72-Exo2. This characteristic is similar to the DNA polymerase I produced by Psychrobacillus sp., which is a marine psychrophilic bacterium that is able to perform DNA synthesis at ambient temperature [8].

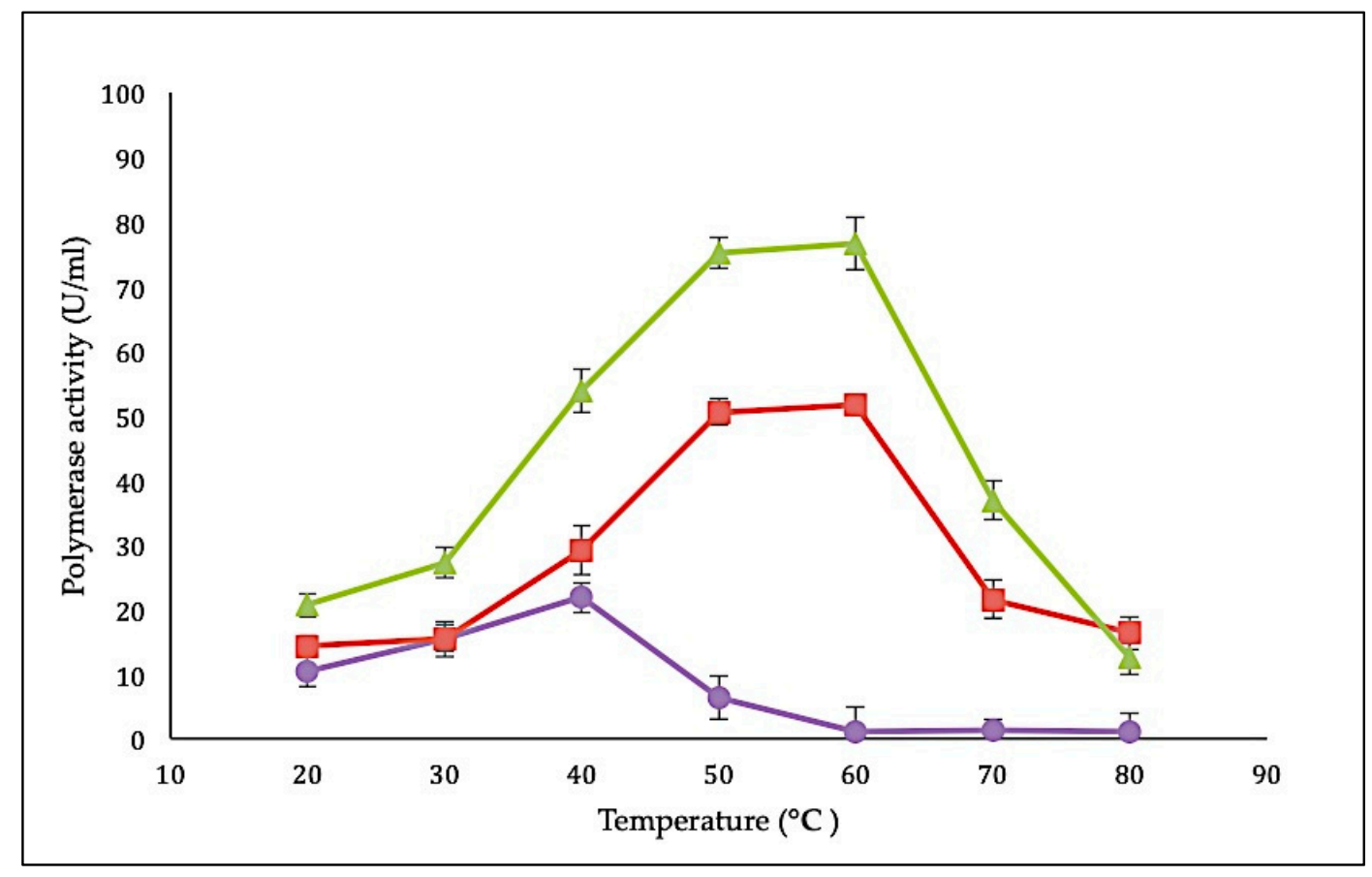

Figure 4. Effect of temperature on SK72 DNA polymerase activity and its variants. Optimal temperature was determined by varying the assay temperatures. Symbols represent the enzyme variants; SK72 (filled square), SK72-Exo (filled triangle), and SK72-Exo2 (filled circle). Error bars represent standard deviation $(n=3)$ The absence of the bar indicates that the error is smaller than the symbols.

\subsubsection{Effect of $\mathrm{pH}$ on $\mathrm{SK} 72$ Polymerase Activity and Its Variants}

The effect of $\mathrm{pH}$ on purified SK72 DNA polymerase and its variants was tested on different $\mathrm{pH}$ ranging from 4 to 11 . The full-length SK72 polymerase showed maximum activity at $\mathrm{pH} 9$ similar to that of SK72-Exo, suggesting that both enzymes preferred alkaline environment to work. SK72-Exo continued to show improvement by obtaining the highest catalytic activity and displayed a broader $\mathrm{pH}$ profile with higher activity at $\mathrm{pH} 8$ to 9 . Wang et al. reported that a superoxide dismutase (SOD) from Bacillus subtilis contained an extra 244 residue on the N-terminal domain (NTD) exhibiting a slight effect on the $\mathrm{pH}$ profile upon the NTD deletion that changes from $\mathrm{pH} 4$ to $\mathrm{pH} 5$ [33]. Meanwhile, the effect of truncation of the GST-C domain in AMS3 lipase from Pseudomonas sp. also promotes similar optimum $\mathrm{pH}$ activity with its native enzyme at $\mathrm{pH} 8$ [30]. This showed that removing the $5^{\prime}-3^{\prime}$ 
exonuclease domain does not greatly impact the overall structure and function of the polymerase, since neither major changes occurred in the $\mathrm{pH}$ profile.

In contrast, the SK72-Exo2 $\mathrm{pH}$ profile was shifted to $\mathrm{pH} 7$ and decreased gradually starting from $\mathrm{pH} 8$ to $\mathrm{pH} 11$ (Figure 5). The effect was that it tremendously changed the ionic environment, which might have been caused by the reduction of the high number of positive and negatively charged residues and the localization of the exonuclease domain. Among the 469 residues that were removed, 72 residues carried a positive charge ( 26 arginine, 37 lysine, and 9 histidine), while 79 residues carried a negative charge (30 aspartic acid and 49 glutamic acid). These residues contribute to the pKa of the enzyme, and the deletion of this high number of important residues may greatly impact the ionic interaction [30]. As compared to SK72-Exo, the $3^{\prime}-5^{\prime}$ exonuclease domain was located toward the polymerase active site separated by a linker region that was covalently attached with the polymerase domain. Thus, deleting this domain structure may influence the overall structure and dynamics of the enzyme [21]. A study by Du et al. reported that the truncation of the $\mathrm{N}$-terminal domain of an invertase (uninv2) shifted the optimal $\mathrm{pH}$ from $\mathrm{pH} 4.5$ to 6.0, which was caused by the changes on the pKa values and electrostatic potential of the ionizable groups on the active sites. Even though the $\mathrm{N}$-terminal domain does not carry any enzymatic activity, it may disturb the pKas of the catalytic residues [34,35]. The absence of the N-terminal exonuclease strongly improved the characteristic of SK72 DNA polymerase I. Meanwhile, deletion of the $3^{\prime}-5^{\prime}$ exonuclease domain had a severe effect on the ionic interfaces of the enzyme.

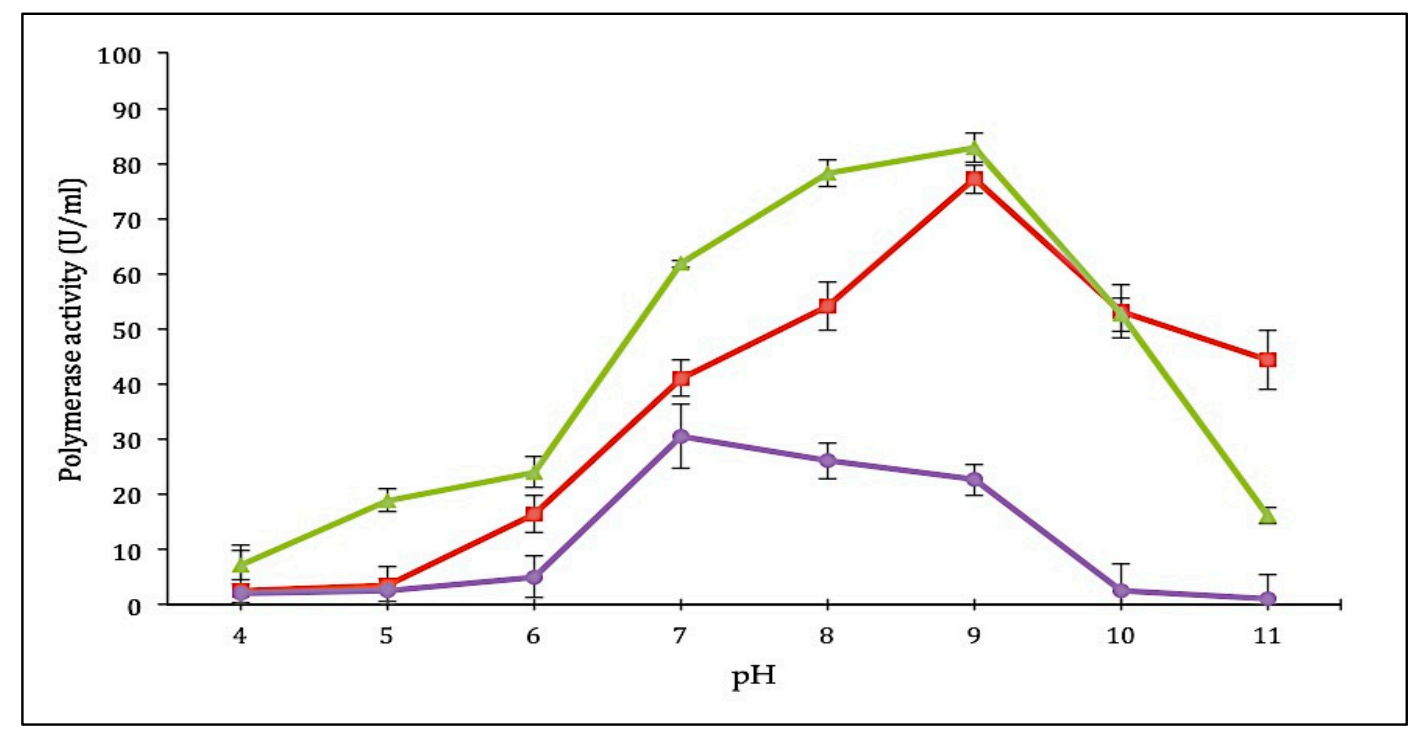

Figure 5. $\mathrm{pH}$ profile of SK72 DNA polymerase and its variants. Symbols represent the enzyme variants; SK72 (filled square), SK72-Exo (filled triangle), and SK72-Exo2 (filled circle). The optimal pH was determined by measuring the enzyme activity in different buffer systems ranging from $\mathrm{pH} 4$ to 11. The error bars represent standard deviation $(n=3)$. The absence of the bar indicates that the error is smaller than the symbols.

\subsubsection{Effect of $\mathrm{MgCl}_{2}$ Concentration on SK72 Polymerase Activity and Its Variants}

Specific metal ions are often involved in enhancing the catalytic activity of an enzyme. Magnesium $\left(\mathrm{Mg}^{2+}\right)$ ions play a critical role in facilitating the polymerization reaction. In this study, the influence of $\mathrm{Mg}^{2+}$ ions on polymerase activity was tested at various concentrations ranging from 0 to $5 \mathrm{mM}$. Polymerase activity was determined relative to control conditions in the absence of any metal ions (Figure 6). For SK72, the polymerase activity was stimulated maximally at $3 \mathrm{mM}$, similar to SK72-Exo2. Both enzymes also showed decreased activity when supplied with higher $\mathrm{MgCl}_{2}$ concentration. Unlike the full-length form, SK72-Exo showed a broader concentration range, with a maximum at $4 \mathrm{mM}$. More than $60 \%$ of activity was observed when supplemented with $\mathrm{Mg}^{2+}$ as low as $1 \mathrm{mM}$, but it 
showed a reduction of $20 \%$ of its activity at $5 \mathrm{mM}$. The Stoffel fragment of Taq polymerase also needed a higher concentration of $\mathrm{Mg}^{2+}$ for optimal activity compared to the full-length Taq polymerase I [36,37]. RKOD DNA polymerase also exhibited high optimum activity at $2 \mathrm{mM}$ [38]. This demonstrates that a minimum concentration of $3 \mathrm{mM}$ was sufficient to obtain the maximum enzyme activity. Conversely, without any addition of $\mathrm{MgCl}_{2}$ into the reaction, the polymerase activity was greatly impaired with almost no activity, suggesting that a divalent metal ion was needed in every polymerization reaction. This shows that the removal of both extra domains in DNA polymerase I does not give any detrimental effect on the binding of metal ion toward the catalytic site.

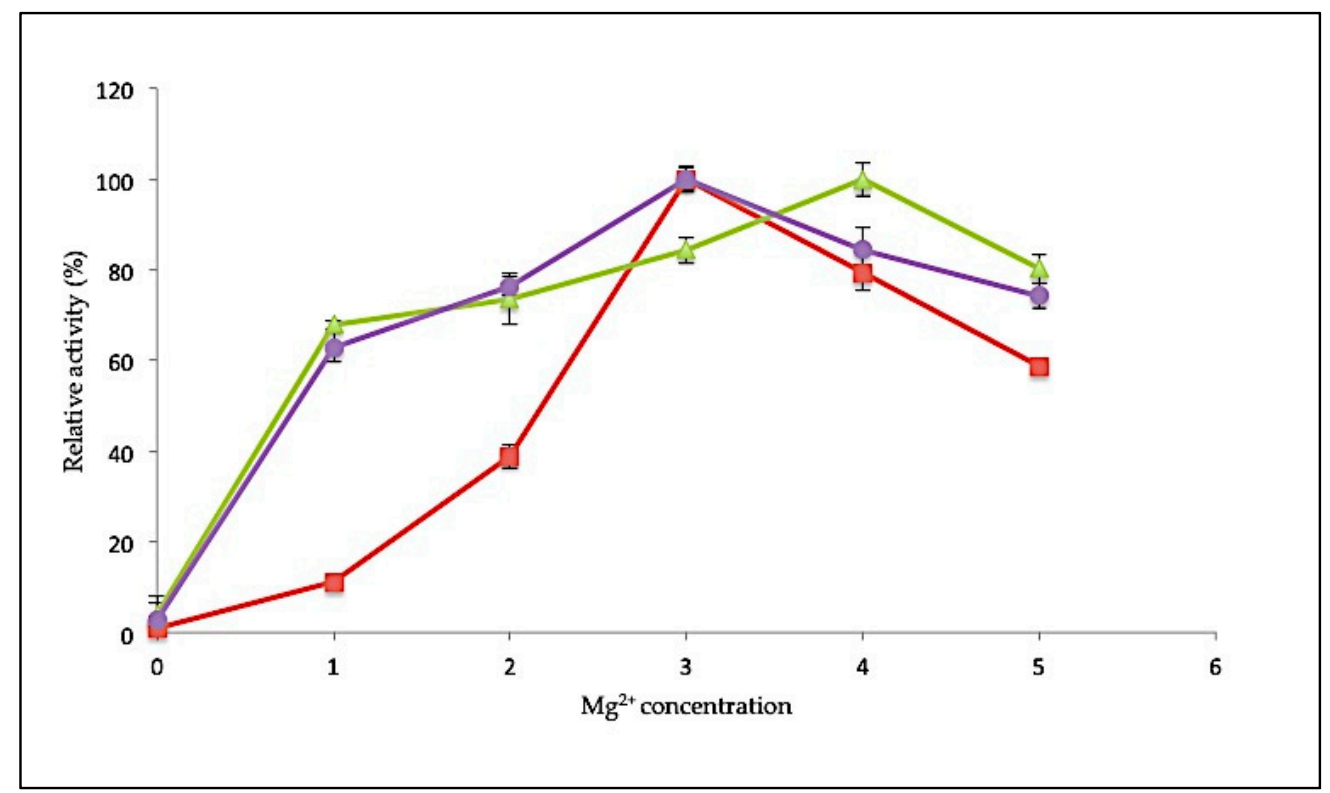

Figure 6. Effect of magnesium ion concentration toward SK72 DNA polymerase I activity and its variants. Note: SK72 (red), SK72-Exo (green), and SK72-Exo2 (purple). The assay took place at optimum temperature for each variant and incubation for $30 \mathrm{~min}$. The control consists of an absence of metal ions $(0 \mathrm{mM})$ relative to the maximal activity for each experiment. Error bars represent standard deviation $(n=3)$. Absence of the bar indicates that the error is smaller than the symbols.

\subsubsection{Thermostability of SK72 Polymerase Activity and Its Variants}

The SK72 DNA polymerase I and its variants were earlier identified as a slightly thermostable enzyme that was remarkably active at temperatures ranging from 40 to $60{ }^{\circ} \mathrm{C}$. Apart from the effect of N-terminal domain deletion on the temperature and $\mathrm{pH}$ profile, this large fragment of SK72 DNA polymerase I could synergistically increase the protein stability and rigidity. A strong conformational structure is a key factor in enzyme stabilization. On this relevance, Figure 7 denotes the thermostability study of SK72 DNA polymerase as compared to its variants at three different temperatures: 50, 60, and $70{ }^{\circ} \mathrm{C}$. Excellent stability was observed in SK72-Exo, where it was able to maintain almost $80 \%$ of its activity throughout the total incubation period at 50 and $60^{\circ} \mathrm{C}$ but decreasing at $70{ }^{\circ} \mathrm{C}$ after $20 \mathrm{~min}$ of incubation. Meanwhile, SK72 was only able to retain half of its activity up to 60 min both at 50 and $60{ }^{\circ} \mathrm{C}$ and dropping drastically after $10 \mathrm{~min}$ of incubation at $70{ }^{\circ} \mathrm{C}$.

In another related study, the truncated $5^{\prime}$-nuclease domain in Taq polymerase also showed higher thermostability compared to its full length. It is hypothesized that the $5^{\prime}$-nuclease domain might be considered as a flexible domain [36,39]. Deletion of the flexible domain has enhanced the protein stability due to reducing the number of unfolded conformations, which was also proven in SK72-Exo [40]. In the case of SK72-Exo2, it demonstrated a loss of activity for all temperatures within the first $10 \mathrm{~min}$ of incubation, as the optimum temperature profile previously also fell sharply at $50{ }^{\circ} \mathrm{C}$. Thermostability in enzymes is often linked with the presence of the disulfide bond formed by 
cysteine residues [41,42]. Based on the amino sequence analysis, deletion of the $5^{\prime}-3^{\prime}$ exonuclease domain did not remove the existing disulfide bridge based on the native form. Meanwhile, deleting the $3^{\prime}$-nuclease domain removed one cysteine residue on the sequence, thus impairing the disulfide bond formation. This shows that absence of the $3^{\prime}$-nuclease domain promotes an extensive effect on the structure integrity and rigidity of SK72 DNA polymerase I.

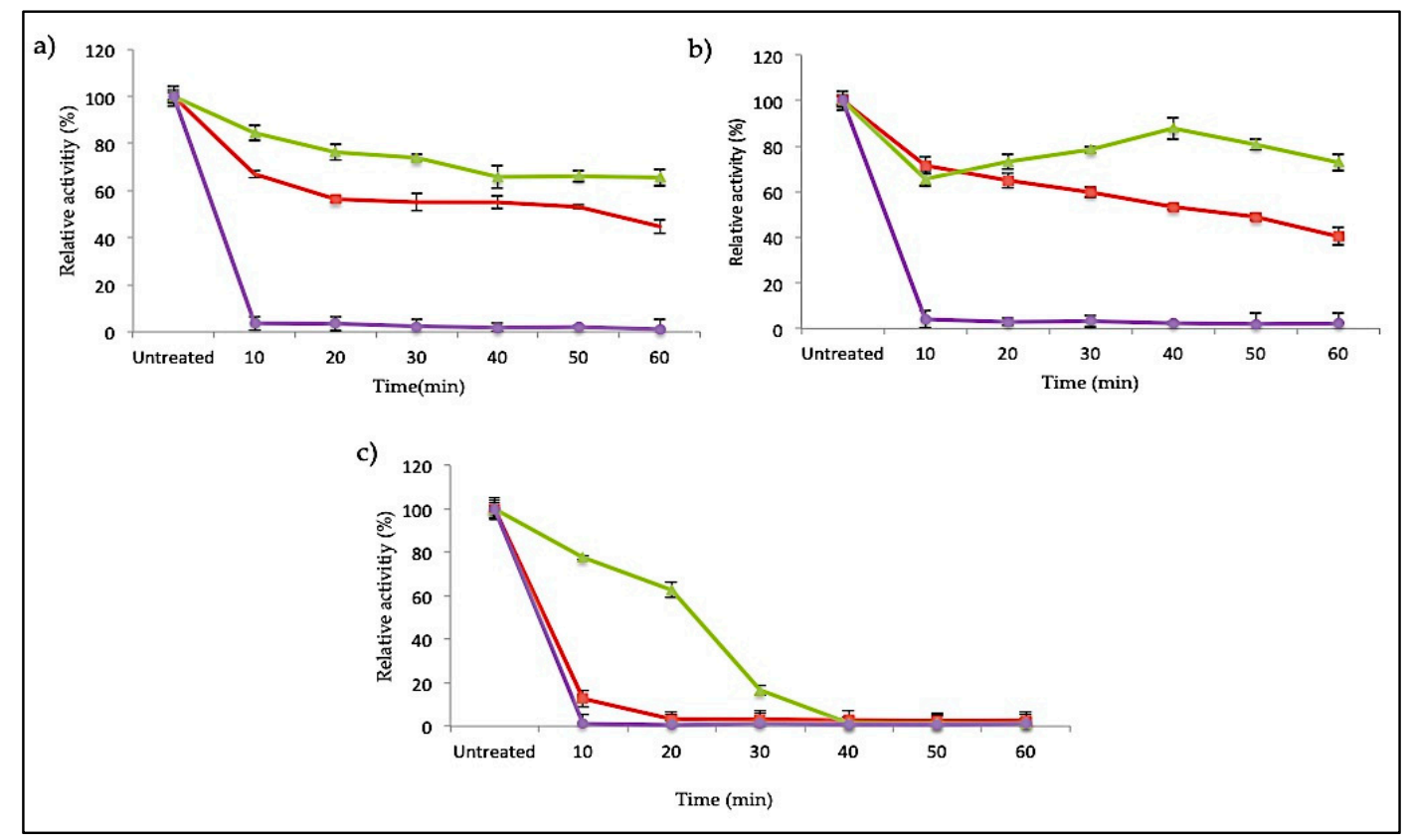

Figure 7. Thermal stability profile of SK72 DNA polymerase and its variants. (a) $50{ }^{\circ} \mathrm{C},(\mathbf{b}) 60^{\circ} \mathrm{C}$, and (c) $70{ }^{\circ} \mathrm{C}$. Purified enzymes were pre-incubated for $30 \mathrm{~min}$ at different temperatures prior to polymerase assay at the optimum temperature of each variant. Untreated enzymes were measured relative to the activity of the enzymes without pre-incubation. Symbols represent the enzyme variants; SK72 (filled triangle), SK72-Exo (filled square), and SK72-Exo2 (filled circle). Error bars represent standard deviation $(n=3)$. The absence of the bar indicates that the error is smaller than the symbols.

\subsection{Thermal Denaturation Analysis of SK72 DNA Polymerase I and Its Variants}

Further thermal stability study was conducted using a JASCO J810-spectrapolarimeter (JASCO, Tokyo, Japan). Measurement was conducted at $222 \mathrm{~nm}$ for temperature ranging from 20 to $90{ }^{\circ} \mathrm{C}$. Generally, soluble globular proteins will undergo structural rearrangement as the temperature environment rises. Throughout the increasing amount of heat applied, the folded protein structure will start to deteriorate until it reaches its melting temperature (Tm). In these studies, the midpoint between the folded and unfolded state of the SK72 DNA polymerase I and its variants was obtained (Figure 8. For both SK72 and SK72-Exo, the $\mathrm{T}_{\mathrm{m}}$ values were $69.84^{\circ} \mathrm{C}$ and $71.01{ }^{\circ} \mathrm{C}$, respectively. The full-length Taq polymerase and its Stoffel fragment exhibit a similar half-life at $97.5^{\circ} \mathrm{C}$, but the Stoffel fragment promotes longer resistance [37]. Meanwhile, the SK72-Exo2 thermal denaturation profile was adjusted to the left with $\mathrm{T}_{\mathrm{m}}$ of $46.22^{\circ} \mathrm{C}$. The effect of removing the central $3^{\prime}-5^{\prime}$ exonuclease domain tremendously changed the overall structure stability of the polymerase, resulting in a lower melting point. This also in correlation with the thermostability result that previously showed an activity drop at $50{ }^{\circ} \mathrm{C}$, which may be caused by the loss of disulfide bridge formation. The location of the first Cys390 was at the $3^{\prime}$-exonuclease domain, while the second Cys847 was located at the $5^{\prime}$-polymerase domain. Thus, deleting the $3^{\prime}$-exonuclease domain disrupts the only disulfide bond that is connected by these residues, resulting in a decrease of the melting point. A similar result was also obtained upon the mutation within the PHP domain in Pol III, suggesting that a decrease in $\mathrm{T}_{\mathrm{m}}$ values highlights that the non-catalytic domain was structurally integrated with the rest of the polymerase as 
one unit [20]. Thus, this major thermal shift suggested that the $3^{\prime}-5^{\prime}$ exonuclease domain does bring a structural support to the overall structure and stability of the protein.
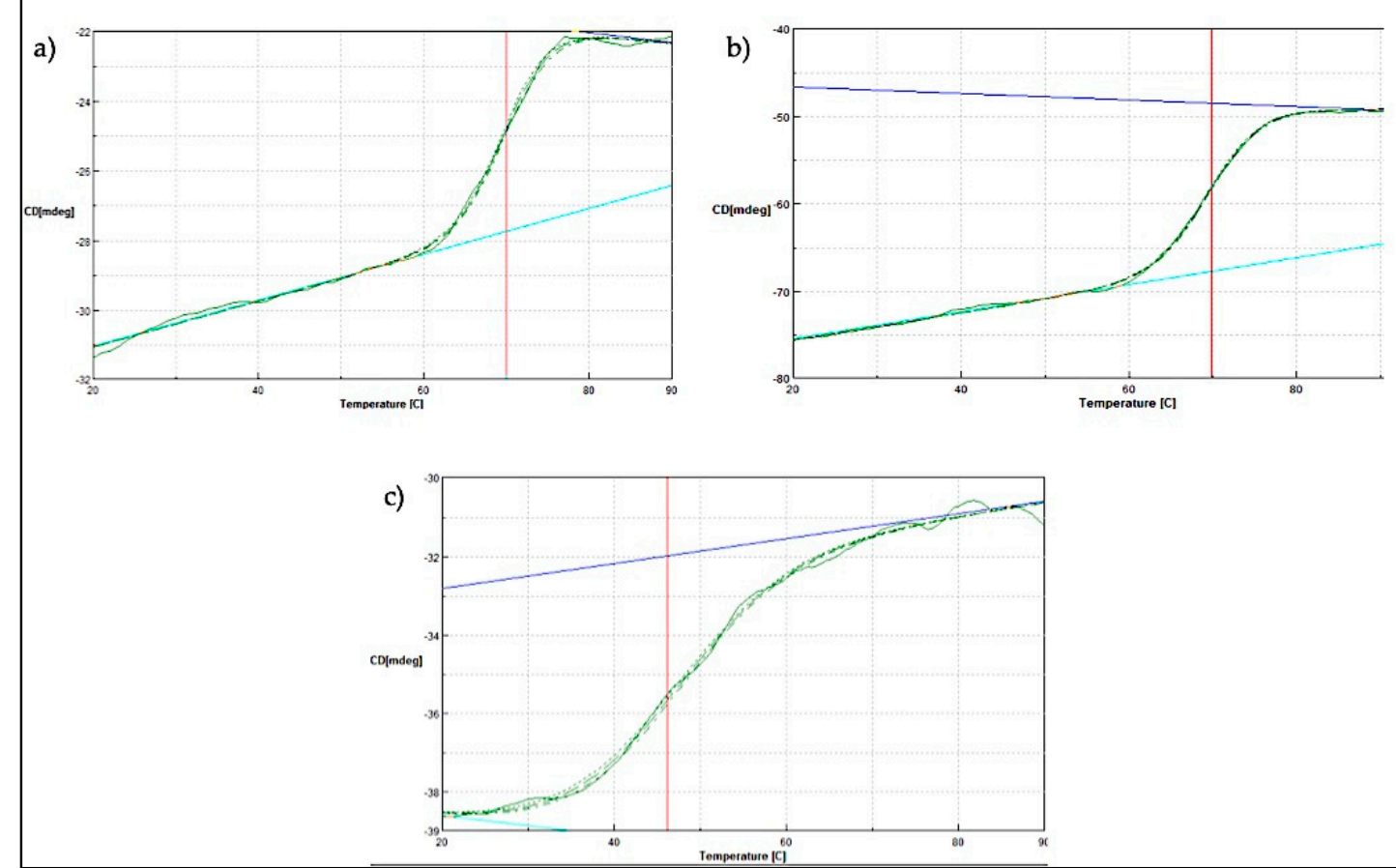

Figure 8. Thermal denaturation profile of SK72 DNA polymerase and its variants. (a) SK72, (b) SK72-Exo, (c) SK72-Exo2. Vertical line (red) indicating the melting point value of each variant when tested from temperatures ranging from 20 to $90{ }^{\circ} \mathrm{C}$.

\subsection{Secondary Structure Analysis of SK72 DNA Polymerase I and Its Variants}

Circular dichroism (CD) measurements have been widely used to follow the equilibrium between helical structures and unordered conformations. The CD spectra (molecular ellipticity) of SK72 DNA polymerase I was analyzed between 190 and $260 \mathrm{~nm}$ at $25^{\circ} \mathrm{C}$. Wavelengths at 220 and $190 \mathrm{~nm}$ were set to monitor the transition of $\alpha$-helix and $\beta$-strand structures, respectively, as they exhibited characteristic signals at this wavelength. A summary of the secondary structure estimation is presented in Table 1 . The stability of the protein structure is often linked to its overall helical and strand content. Here, the percentage of $\alpha$-helix took most of the variant's structure with SK72-Exo being the highest, followed by SK72 and SK72-Exo2. The effect of truncation also decreased the amount of strand structure gradually, as can be seen in Figure 2. The overall structure of SK72 DNA polymerase was mainly made up by a helical structure that covered the $\beta$-sheet where the catalytic region resided. As expected, the high percentage of $\alpha$-helix content enhanced the stability and activity of SK72-Exo. Meanwhile, the removal of the $3^{\prime}$-exonuclease domain decreased the protein stability due to loss of the protein secondary structure, followed by an increased in the disordered conformation.

Table 1. Secondary structure content determination.

\begin{tabular}{cccc}
\hline & \multicolumn{3}{c}{ Amount of Secondary Structure (\%) } \\
\cline { 2 - 4 } & SK72 & SK72-Exo & SK72-Exo2 \\
\hline Helix & 47.0 & 49.1 & 45.0 \\
Sheet & 18.5 & 12.9 & 5.5 \\
Turn & 11.4 & 17.8 & 19.6 \\
Coil & 23.1 & 20.3 & 29.9 \\
\hline
\end{tabular}




\section{Materials and Methods}

\subsection{Strains, Vectors, and Growth Medium}

The Geobacillus sp. strain SK72 used in this research was obtained from Enzyme and Microbial Technology Research Centre, Faculty of Biotechnology and Biomolecular Sciences, Universiti Putra Malaysia. The bacterium was previously isolated from the Sungai Kelah hot spring in Perak, Malaysia. Escherichia coli strains TOP10 and BL21 (DE3) were purchased from Novagen (Merck, Darmstadt, Germany). The pGEM-T Easy was purchased from Promega (Madison, Wisconsin, USA), and expression vector pET28a was obtained from Enzyme and Microbial Technology Research Centre, Faculty of Biotechnology and Biomolecular Sciences, Universiti Putra Malaysia. Nutrient agar and broth media were purchased from Merck (Darmstadt, Germany). E. coli Luria-Bertani (LB) agar and broth growth media were purchased from Merck (Germany).

\subsection{Isolation of SK72 DNA Polymerase I Gene}

Genomic DNA of Geobacillus sp. SK72 was isolated according to a standard procedure by Qiagen (Hilden, Germany). DNA polymerase I genes of seven (7) related species including Anoxybacillus sp. NB, Geobacillus stereothermophilus, Geobacillus thermodenitrificans, Geobacillus caldoxylosilyticu, Bacillus caldotenax, Thermus thermophiles strain HJ6, and Thermus filiformis RT41A obtained from the National Centre for Biotechnology Information (NCBI) (www.ncbi.nlm.nih.gov/blast/) were used to perform multiple sequences alignments and were selected for degenerate primers design.

The primers termed as F-degenerate (GAYTAYTCGCAAATYGARYTG) and R-degenerate (GAGYTCGTCATGSACYTG) were used to PCR amplify the gene fragment on a thermocycler (Bio-Rad, Hercules, CA, USA) in a $20 \mu \mathrm{L}$ reaction mixture containing $100 \mathrm{ng}(1 \mu \mathrm{L})$ of template DNA, $0.25 \mu \mathrm{M}$ $(0.5 \mu \mathrm{L})$ each of forward and reverse primers, $2 \mu \mathrm{L}$ of 10XTaq polymerase buffer, $1.5 \mathrm{mM}(1.2 \mu \mathrm{L})$ of $\mathrm{MgCl}_{2}, 25 \mathrm{U}(0.10 \mu \mathrm{L})$ of Taq DNA polymerase, and $14.2 \mu \mathrm{L}$ of distilled water. The PCR incubation conditions were set to have an initial denaturation temperature at $95{ }^{\circ} \mathrm{C}$ for $3 \mathrm{~min}$, followed by 25 cycles at $95^{\circ} \mathrm{C}$ for $1 \mathrm{~min}, 50.0^{\circ} \mathrm{C}$ for $1 \mathrm{~min}$, and $68.0^{\circ} \mathrm{C}$ for $2 \mathrm{~min}$ and $15 \mathrm{~s}$, followed by a final extension at $68.0{ }^{\circ} \mathrm{C}$ for $10 \mathrm{~min}$. The PCR product was analyzed on $1.0 \%(w / v)$ agarose gel. The amplified fragment showed high identity to certain regions of DNA polymerase I genes in Geobacillus kaustohilus (BA000043.1) (100\%), Bacillus sp. G (EF198253.1) (99\%), and Geobacillus kaue strain E1 (FJ215761.1) (88\%).

\subsection{Cloning of SK72 DNA Polymerase I}

Subsequently, F-SK72 pol (ATGAGATTGAAAAAAAAGCTTGTTTTA) and R-SK72 pol (TTATTTCGCGTCATACCATGTCGAG) primers were designed from the flanking regions of the Geobacillus kaue strain E1 (FJ215761.1) DNA polymerase I gene and used for another round of PCR with the same incubation conditions mentioned above to amplify the SK72 pol. All the gene fragments obtained during the cloning steps were purified by gel extraction (Qiagen, Hilden, Germany) and directly sequenced before or after ligation into pGEM-T Easy (Promega, Madison, WI, USA).

\subsection{Nucleotide Sequencing and Amino Acid Analysis}

All PCR products and successful ligated products were sequenced at First Base Sdn Bhd (Apical Scientific, Selangor, Malaysia). Sequence analysis was performed using Basic Local Alignment Tools (BLAST) at the National Centre for Biotechnology Information (NCBI) (www.ncbi.nlm.nih.gov/ blast/). Multiple sequences alignments were done using the CLUSTAL W Programme [43]. A full nucleotide (accession no.: MG190359.1) and amino acid (accession no.: AXU98681.1) sequence were submitted into the GenBank database. 


\subsection{Domains Analysis of SK72 DNA Polymerase and Its Variants}

The conserved domains were identified using the Conserved Domain Search (CDS), InterPro Scan, and Protein Families (Pfam) database. Then, the secondary structure prediction was performed using online tools-namely, PSI-blast based secondary structure prediction (PSIPRED), coupled with comparative modeling software called YASARA to confirmed the domain boundaries and initial codon for each variants. Both tools used the closest structure for each variant against the Protein Data Bank (PDB) database. Then, all predicted models were evaluated for the reliability of the structure using four automated servers, namely ERRAT [44], Verify 3D [45], QMEAN [46], and Ramachandran plot developed by RAMPAGE (http://www-cryst.bioc.cam.ac.uk/).

\subsection{Construction of SK72 Pol and Its Variants}

SK72. A full-length gene of the SK72 DNA polymerase I was PCR amplified from the synthesized vector, $\mathrm{pUCIDT}$, using the SK72-F1 and SK72-R1 primers listed in Table 2. The underlined sequences are restriction sites for XbaI and SalI enzymes in the forward and reverse primers, respectively. The amplified products $(2.6 \mathrm{~kb})$ were purified using a gel extraction kit (Qiagen, Germany), treated with NdeI and SalI restriction enzymes, ligated into a pET28a expression vector, and transformed into E. coli BL21 (DE3). Positive transformants were screened on an LB agar plate incorporated with $50 \mu \mathrm{g} / \mathrm{mL}$ of kanamycin at $37^{\circ} \mathrm{C}$ overnight. The recombinant plasmid designated pET28/SK72 was validated by colony PCR, enzymes digestion, and sequencing.

Table 2. List of primers used for subcloning into a pET28 expression vector.

\begin{tabular}{ccc}
\hline Primer Name & Sequence $\mathbf{( 5}^{\prime} \mathbf{- 3}^{\prime} \mathbf{)}$ & Restriction Site \\
\hline SK72-F1 & ATCCCATATGATGCGCCTGAAAAAAAAACTGGTGCTGATTG & NdeI \\
SK72-R1 & TGCGTCGACTCATTTGGCATCATACCAAGTAC & SalI \\
SK72-Exo-F2 & GAAACATATGGCCAAAATGGCGTTTACGCTGGC & NdeI \\
SK72-Exo2-F3 & GCTTCATATGAATGAACAGGATCGGCTGCTGGTG & NdeI \\
\hline
\end{tabular}

SK72-Exo. The partial N-terminus SK72 DNA polymerase I, known as a large fragment, encodes for the $3^{\prime}-5^{\prime}$ exonuclease and $5^{\prime}-3^{\prime}$ polymerization domain amplified from the pUCIDT vector using SK72-Exo-F2/SK72-R1 primers. The resultant 1.75-kbp DNA fragments and pET28 were digested with NdeI and SalI, ligated, and transformed into E. coli BL21 (DE3) according to the standard protocol. The recombinant plasmid designated as pET28/SK72-Exo was validated by colony PCR, enzymes digestion, and sequencing.

SK72-Exo2. The partial C-terminus SK72 DNA polymerase I (deleted both $5^{\prime}-3^{\prime}$ and $3^{\prime}-5^{\prime}$ exonuclease) nucleotide sequence was amplified from the pUCIDT vector using SK72-Exo2-F3/SK72-R1 primers. The resulting 1.2-kbp DNA fragments and pET28 were digested with NdeI and SalI, followed by ligation, and transformed into E. coli BL21 (DE3) according to the standard protocol. The obtained recombinant plasmid was purified, digested, and further validated by sequencing. The resultant plasmid was named pET28/SK72-Exo.

\subsection{Expression and Purification of SK72 Polymerase I and Its Variants}

Successfully transformed colonies of E. coli BL21 (DE3) that carried the recombinant expression vector pET28/SK72 were cultured in $200 \mathrm{~mL}$ of LB broth in a $1 \mathrm{~L}$ conical flask in the presence of kanamycin to an optical density (OD) of 0.5 . The overexpressed E. coli cells were induced using IPTG to a final concentration according to the constructs. The cells were harvested by centrifugation $(8000 \times \mathrm{g}, 20 \mathrm{~min})$ after $12 \mathrm{~h}$ of induction, and the pellet was suspended in $10 \mathrm{~mL}$ of phosphate buffer ( $\mathrm{pH}$ 7.4). The cells were lysed by sonication, and the insoluble fraction was removed by centrifugation ( $4000 \times g, 20 \mathrm{~min})$. Purification was performed using $\mathrm{Ni}^{2+}$-Sepharose affinity chromatography aided by a AKTA Protein Purification System (GE, Chicago, IL, USA). The soluble fraction of the cell lysates was equilibrated with binding buffer ( $\mathrm{pH} 7.4,30 \mathrm{mM}$ imidazole) and loaded into a $5 \mathrm{~mL}$ HisTrap FF 
(GE, Chicago, IL, USA). The unbound protein was washed away from the column by the binding buffer at a flow rate of $1 \mathrm{~mL} / \mathrm{min}$, and the bound protein was eluted with elution buffer $(\mathrm{pH} 7.4,500 \mathrm{mM}$ imidazole) in a gradient imidazole concentration. The eluted fractions were collected and analyzed by SDS-PAGE on $10 \%$ gel.

\subsection{Polymerase Activity Assay}

Characterization of the SK72 DNA polymerase activity and its variants were performed by incorporating a radiolabeled nucleotide during DNA polymerization synthesis [29]. A reaction mixture $(50 \mu \mathrm{L})$ containing $25 \mathrm{mM}$ Tris- $\mathrm{Cl}, 4 \mathrm{mM} \mathrm{MgCl}_{2}, 25 \mu \mathrm{M}$ deoxynucleoside triphosphate (dNTP), $0.5 \mu \mathrm{Ci}$ thymidine triphosphate (TTP) [methyl- $\left.\mathrm{H}^{3}\right], 0.2 \mathrm{mg} / \mathrm{mL}$ bovine serum albumin (BSA), $0.1 \%$ Tween 20, $5 \mu \mathrm{g}$ activated calf thymus DNA, and $100 \mu \mathrm{g}$ of SK72 DNA polymerase was prepared. The enzyme assay was performed at $60^{\circ} \mathrm{C}$ for $30 \mathrm{~min}$ and spotted the mixture on a glass fiber filter disc. The filter was air dried, washed twice with $0.5 \mathrm{M}$ sodium phosphate $\mathrm{pH} 7.0$, and dried with $70 \%$ ethanol. The filter was placed into a scintillation vial, and $2 \mathrm{~mL}$ of scintillation fluid was added into the vial. The radioactivity of the incorporated nucleotides was measured using a Packard Liquid Scintillation Counter (Perkin Elmer, Waltham, MA, USA). One unit of polymerase activity is defined as the rate of incorporation of $10 \mathrm{pmol}$ of the labeled dNTP into the DNA at $60^{\circ} \mathrm{C}$ in $30 \mathrm{~min}$.

\subsection{Thermal Stability, Optimal Temperature and $\mathrm{pH}$, and $\mathrm{MgCl}_{2}$ Concentration Analyses}

For thermal stability, purified SK72 DNA polymerase and its variants were incubated at three different temperatures $\left(50,60\right.$, and $\left.70{ }^{\circ} \mathrm{C}\right)$ for one hour. The incubated samples were immediately chilled on ice, and the enzyme activity was determined using the standard polymerase assay conditions described above. The temperature and $\mathrm{pH}$ optimum of the enzyme was investigated by measuring the polymerase activity at a range of 20 to $90{ }^{\circ} \mathrm{C}$ and from $\mathrm{pH} 4$ to $\mathrm{pH} 11$, respectively based on the protocol described above for the polymerase activity assay. The optimal ion concentration was examined similarly as in the polymerase activity assay, using an $\mathrm{MgCl}_{2}$ concentration in the range of 0 to $5 \mathrm{mM}$.

\subsection{Secondary Structure and Melting Point Estimation}

The thermal stability and the secondary structure estimation of the enzymes were analyzed by heating in circular dichroism. For secondary structure estimation, the reactions were conducted in $500 \mu \mathrm{L}$ containing $0.2 \mathrm{mg} / \mathrm{mL}$ enzyme and $10 \mathrm{mM}$ sodium phosphate storage buffer. The temperature was set at $20^{\circ} \mathrm{C}$, and the absorbance was read ranging from 260 to $190 \mathrm{~nm}$. The melting point was examined with total reactions containing $5 \mathrm{~mL}$ of $2 \mathrm{mg} / \mathrm{mL}$ enzyme and $5 \mathrm{mM}$ sodium phosphate storage buffer. The temperature was increased from 20 to $95{ }^{\circ} \mathrm{C}$, with an increment of $1{ }^{\circ} \mathrm{C}$ per second, and the absorbance signal was collected from wavelength 280 to $190 \mathrm{~nm}$.

\section{Conclusions}

The present work was to compare the effect of the truncation of multiple domains in SK72 DNA polymerase I. The native SK72 and its variants were successfully expressed and purified via single-step affinity chromatography. The removal of the $5^{\prime}-3^{\prime}$ exonuclease domain (SK72-Exo) was found to improve the enzyme activity but maintain the temperature and $\mathrm{pH}$ profile similar to the native SK72 at $60^{\circ} \mathrm{C}$ and $\mathrm{pH} 9$, respectively. SK72-Exo promoted better thermostability compared to the two other variants; it was able to retain almost $80 \%$ of its activity at 50 and $60{ }^{\circ} \mathrm{C}$ for an hour, and decreasing at $70^{\circ} \mathrm{C}$ after $20 \mathrm{~min}$. Deletion of the flexible domain (5'-3' exonuclease), which contains a high number of $\alpha$-helix structures, may contribute to the enhancement of enzyme activity and stability. Meanwhile, the effect of deletion on both $\mathrm{N}$-terminal domains (SK72-Exo2) caused an extensive effect toward the polymerase catalytic activity that collapsed the overall polymerase structure and function. Thus, we conclude that the $3^{\prime}-5^{\prime}$ exonuclease domain is considered as a major structural domain instead of carrying any catalytic activity. This is also linked to the location of the $3^{\prime}-5^{\prime}$ exonuclease domain that 
was very close, which covalently linked to the polymerase domain. The improvements of SK72-Exo in catalytic activity and thermostability were also seen between the Stoffel fragments in Taq DNA polymerase I and its wild type [37], but there were none in Geobacillus sp. In addition, the effect of cutting both exonucleases diminished the core catalytic domain that displayed similar results to those found in the E. coli DNA polymerase III upon the PHP domain deletion [20]. This is the first report that distinguishes the characteristics of the large fragment of Bst DNA polymerase I from Geobacillus sp. against its full-length form. Thus, a simple engineering technique was performed that provides insights into the effect of major domain deletion in SK72 DNA polymerase as well as family A polymerases.

Author Contributions: Conceptualization, W.H.H. and R.N.Z.R.A.R.; methodology, W.H.H., A.N., and R.N.Z.R.A.R.; validation, R.N.Z.R.A.R., M.S.M.A. and F.M.S.; formal analysis, W.H.H., A.N., and R.N.Z.R.A.R.; investigation, W.H.H.; Resources, R.N.Z.R.A.R., M.S.M.A. and F.M.S.; data curation, W.H.H. and R.N.Z.R.A.R.; writing (review and editing) W.H.H., and R.N.Z.R.A.R.; visualization, W.H.H. and R.N.Z.R.A.R.; supervision, R.N.Z.R.A.R., M.S.M.A. and F.M.S.; project administration, R.N.Z.R.A.R.; funding acquisition, R.N.Z.R.A.R., M.S.M.A. and F.M.S. All authors have read and agreed to the published version of the manuscript.

Funding: Putra Grant funded this research, (GP-IPS/2017/9600800).

Acknowledgments: W.H.H. was supported by Graduate Research Fellowship (GRF) fund and research grant (GP-IPS/2017/9600800) from Universiti Putra Malaysia.

Conflicts of Interest: The authors declare no conflict of interest.

\section{References}

1. Kornberg, A.; Baker, T.A. DNA Replication; W.H. Freeman \& Co.: New York, NY, USA, 1992; Volume 3.

2. Garcia-Diaz, M.; Bebenek, K. Multiple functions of DNA polymerases. Crit. Rev. Plant Sci. 2007, 26, 105-122. [CrossRef] [PubMed]

3. Rittie, L.; Perbal, B. Enzymes used in molecular biology: A useful guide. J. Cell Commun. Signal. 2008, 2, 25-45. [CrossRef] [PubMed]

4. Braithwaite, D.; Ito, J. Compilation, alignment, and phylogenetic relationships of DNA polymerases. Nucleic Acids Res. 1993, 21, 787. [CrossRef]

5. Hubscher, U.; Maga, G.; Spadari, S. Eukaryotic DNA polymerases. Annu. Rev. Biochem. 2002, 71, $133-163$. [CrossRef]

6. Ishino, S.; Ishino, Y. DNA polymerases as useful reagents for biotechnology-The history of developmental research in the field. Front. Microbiol. 2014, 5, 465. [CrossRef] [PubMed]

7. Sahoo, P.R.; Sethy, K.; Mohapatra, S.; Panda, D. Loop mediated isothermal amplification: An innovative gene amplification technique for animal diseases. Vet. World 2016, 9, 465-469. [CrossRef] [PubMed]

8. Piotrowski, Y.; Gurung, M.K.; Larsen, A.N. Characterization and engineering of a DNA polymerase reveals a single amino-acid substitution in the fingers subdomain to increase strand-displacement activity of A-family prokaryotic DNA polymerases. BMC Mol. Cell Biol. 2019, 20, 31. [CrossRef] [PubMed]

9. Steitz, T.A. DNA Polymerases: Structural Diversity and Common Mechanisms. J. Biol. Chem. 1999, 274, 17395-17398. [CrossRef]

10. Lovett, S.T. The DNA exonucleases of Escherichia Coli. EcoSal Plus 2011, 4, 10. [CrossRef]

11. Joyce, C.M.; Steitz, T.A. Function and Structure Relationship in DNA Polymerase. Annu. Rev. Biochem. 1994, 63, 777-822. [CrossRef]

12. Phang, S.M.; Teo, C.Y.; Lo, E.; Wong, V.W. Cloning and complete sequence of the DNA polymerase-encoding gene (BstpolI) and characterisation of the Klenow-like fragment from Bacillus stearothermophilus. Gene 1995, 163, 65-68. [CrossRef]

13. Kiefer, J.R.; Mao, C.; Hansen, C.J.; Basehore, S.L.; Hogrefe, H.H.; Braman, J.C.; Beese, L.S. Crystal structure of a thermostable Bacillus DNA polymerase 1 large fragment at $2.1 \AA$ resolution. Structure 1998, 5, 95-108. [CrossRef]

14. Oscorbin, I.P.; Boyarskikh, U.A.; Filipenko, M.L. Large Fragment of DNA Polymerase I from Geobacillus sp. 777: Cloning and Comparison with DNA Polymerases I in Practical Applications. Mol. Biotechnol. 2015, 57, 947-959. [CrossRef] [PubMed]

15. Shevelev, I.V.; Hübscher, U. The 3'-5' exonucleases. Nat. Rev. Mol. Cell Biol. 2002, 3, 364-376. [CrossRef] 
16. Ishino, Y.; Iwasaki, H.; Kato, I.; Shinagawa, H. Amino acid sequence motifs essential to $3^{\prime}->5^{\prime}$ exonuclease activity of Escherichia coli DNA polymerase II. J. Biol. Chem. 1994, 269, 14655-14660.

17. Aliotta, J.M.; Pelletier, J.J.; Ware, J.L.; Moran, L.S.; Benner, J.S.; Kong, H. Thermostable Bst DNA polymerase I lacks a 3'- 5' proofreading exonuclease activity. Genet. Anal. Biomol. Eng. 1996, 12, 185-195. [CrossRef]

18. Kamarudin, N.H.; Rahman, R.N.; Ali, M.S.; Leow, T.C.; Basri, M.; Salleh, A.B. Unscrambling the effect of C-terminal tail deletion on the stability of a cold-adapted, organic solvent stable lipase from Staphylococcus epidermidis AT2. Mol. Biotechnol. 2014, 56, 747-757. [CrossRef]

19. Lamers, M.H.; Georgescu, R.E.; Lee, S.G.; O'Donnell, M.; Kuriyan, J. Crystal structure of the catalytic a subunit of E. coli replicative DNA polymerase III. Cell 2006, 126, 881-892. [CrossRef]

20. Barros, T.; Guenther, J.; Kelch, B.A.; Anaya, J.; Prabhakar, A.; Odonnell, M.; Kuriyan, J.; Lamers, M.H. A structural role for the PHP domain in E. coli DNA polymerase III. BMC Struct. Biol. 2013, 13, 8. [CrossRef] [PubMed]

21. Vishwanath, S.; Brevern, A.G.; Srinivasan, N. Same but not alike: Structure, flexibility and energetics of domains in multi-domain proteins are influenced by the presence of other domains. PLoS Comput. Biol. 2018, 14, e1006008. [CrossRef]

22. Srivastava, A.; Sinha, S. Thermostability of in vitro evolved Bacillus subtilis lipase A: A network and dynamics perspective. PLoS ONE 2014, 9, e102856. [CrossRef] [PubMed]

23. Federly, R.G.; Romano, L.J. DNA Polymerase: Structural Homology, Conformational Dynamics, and the Effects of Carcinogenic DNA Adducts. J. Nucleic Acids 2010, 2010, 457176. [CrossRef] [PubMed]

24. Santoso, Y.; Joyce, C.M.; Potapova, O.; Reste, L.L.; Hohlbein, J.; Torella, J.P.; Grindley, N.D.F.; Kapinidis, A.N. Conformational transitions in DNA polymerase I revealed by single-molecule FRET. Proc. Natl. Acad. Sci. USA 2010, 107, 715-720. [CrossRef] [PubMed]

25. Choi, K.H. Viral Polymerases. Adv. Exp. Med. Biol. 2012, 726, 267-304.

26. Miller, B.R.; Beese, L.S.; Parish, C.A.; Wu, E.Y. The Closing Mechanism of DNA Polymerase I at Atomic Resolution. Structure 2015, 23, 1609-1620. [CrossRef]

27. San-Miguel, T.; Perez-Bermudez, P.; Gavidia, I. Production of soluble eukaryotic recombinant proteins in E. coli is favoured in early log-phase cultures induced at low temperature. SpringerPlus 2013, 2, 89. [CrossRef]

28. Gutierrezgonzalez, M.; Farias, C.; Tello, S.; Perezetcheverry, D.; Romero, A.; Zuniga, R.; Ribeiro, C.H.; Lorenzoferreiro, C.; Molina, M.C. Optimization of culture conditions for the expression of three different insoluble proteins in Escherichia coli. Sci. Rep. 2019, 9, 16850. [CrossRef]

29. Lee, J.; Cho, S.; Kil, E.; Kwon, S. Characterization and PCR application of a thermostable DNA polymerase from Thermococcus pacificus. Enzym. Microb. Technol. 2010, 47, 147-152. [CrossRef]

30. Latip, W.; Raja Noor, Z.R.; Rahman, A.; Adam Thean, C.L.; Fairolniza, M.S.; Nor Hafizah, A.K.; Mohd Shukuri, M.A. The effect of N-terminal domain removal towards the biochemical and structural features of a thermotolerant lipase from an antarctic Pseudomonas sp. strain AMS3. Int. J. Mol. Sci. 2018, 19, 560. [CrossRef]

31. Lu, Z.; Wang, Q.; Jiang, S.; Zhang, G.; Ma, Y. Truncation of the unique N-terminal domain improved the thermos-stability and specific activity of alkaline $\alpha$-amylase Amy703. Sci. Rep. 2016, 6, 22465. [CrossRef]

32. Lu, Z.; Tian, C.; Li, A.; Zhang, G.; Ma, Y. Identification and characterization of a novel alkaline [alpha]-amylase Amy703 belonging to a new clade from Bacillus pseudofirmus. J. Ind. Microbiol. Biotechnol. 2014, 41, 783-793. [CrossRef] [PubMed]

33. Wang, W.; Ma, T.; Zhang, B.; Yao, N.; Li, M.; Cui, L.; Li, G.; Ma, Z.; Cheng, J. A novel mechanism of protein thermostability: A unique N-terminal domain confers heat resistance to Fe/Mn-SODs. Sci. Rep. 2015, 4, 7284. [CrossRef]

34. Du, L.; Pang, H.; Wang, Z.; Lu, J.; Wei, Y.; Huang, R. Characterization of an Invertase with pH Tolerance and Truncation of Its N-Terminal to Shift Optimum Activity toward Neutral pH. PLoS ONE 2013, 8, e62306. [CrossRef]

35. Kim, S.H.; Subarna, P.; Young, J.Y. Mutation of non-conserved amino acids surrounding catalytic site to shift pH optimum of Bacillus circulans xylanase. J. Mol. Catal. B Enzym. 2008, 55, 130-136. [CrossRef]

36. Śpibida, M.; Krawczyk, B.; Olszewski, M.; Kur, J. Modified DNA polymerases for PCR troubleshooting. J. Appl. Genet. 2017, 58, 133-142. [CrossRef] [PubMed] 
37. Lawyer, F.C.; Stoffel, S.; Saiki, R.K.; Chang, S.Y.; Landre, P.A.; Ambramson, R.D.; Gelfand, D.H. High-level Expression, Purification, and Enzymatic Characterization of Full-length Thermus aquaticus DNA Polymerase and a Truncated Form Deficient in 5' to 3' Exonuclease Activity. PCR Methods Appl. 1993, 2, $275-287$. [CrossRef] [PubMed]

38. Wang, F.; Li, S.; Zhao, H.; Bian, L.; Chen, L.; Zhang, Z.; Zhong, X.; Ma, L.; Yu, X. Expression and Characterization of the RKOD DNA Polymerase in Pichia pastoris. PLoS ONE 2015, 10, e0131757. [CrossRef]

39. Xie, P.; Sayers, J.R. A Model for Transition of 59-Nuclease Domain of DNA Polymerase I from Inert to Active Modes. PLoS ONE 2011, 6, e16213. [CrossRef] [PubMed]

40. Gao, X.; Liu, Z.; Cui, W.; Zhou, L.; Tian, Y.; Zhou, Z. Enhanced Thermal Stability and Hydrolytic Ability of Bacillus subtilis Aminopeptidase by Removing the Thermal Sensitive Domain in the Non-Catalytic Region. PLoS ONE 2014, 9, e92357. [CrossRef] [PubMed]

41. Tahir, H.M.; Rahman, R.N.Z.R.A.; Leow, A.T.C.; Ali, M.S.M. Expression, Characterisation and Homology Modelling of a Novel Hormone-Sensitive Lipase (HSL)-Like Esterase from Glaciozyma antarctica. Catalysts 2019, 10, 58. [CrossRef]

42. Yin, X.; Hu, D.; Li, J.F.; He, Y.; Zhu, T.D.; Wu, M.C. Contribution of Disulfide Bridges to the Thermostability of a Type A Feruloyl Esterase from Aspergillus usamii. PLoS ONE 2015, 10, e0126864. [CrossRef] [PubMed]

43. Larkin, M.; Blackshields, G.; Brown, N.; Chenna, R. Clustal W and Clustal X version 2.0. Bioinformatics 2007, 23, 2947-2948. [CrossRef] [PubMed]

44. Colovos, C.; Yeates, T.O. Verification of Protein Structures: Patterns of Non bonded Atomic Interactions. Protein Sci. 1993, 2, 1511-1519. [CrossRef] [PubMed]

45. Luthy, R.; Bowie, J.U.; Eisenberg, D. Assesment of Protein Models with 3 Dimensional Profile. Nature 1992, 356, 83-85. [CrossRef] [PubMed]

46. Benkert, P.; Künzli, M.; Schwede, T. QMEAN server for protein model quality estimation. Nucleic Acids Res. 2009, 37, 510-514. [CrossRef]

(C) 2020 by the authors. Licensee MDPI, Basel, Switzerland. This article is an open access article distributed under the terms and conditions of the Creative Commons Attribution (CC BY) license (http://creativecommons.org/licenses/by/4.0/). 